\title{
PRCC wt Allele
}

National Cancer Institute

\section{Source}

National Cancer Institute. PRCC wt Allele. NCI Thesaurus. Code C70995.

Human PRCC wild-type allele is located in the vicinity of 1q21.1 and is approximately $33 \mathrm{~kb}$ in length. This allele, which encodes proline-rich protein PRCC, may play a role in the regulation of the mitotic checkpoint or RNA splicing. A chromosomal translocation $t(X ; 1)$ ( $p 11 ; q 21$ ) fuses the gene to the TFE3 gene and is associated with a subset of papillary renal cell carcinomas. 